\title{
A new species of Stilobezzia Kieffer from the Neotropical Region (Diptera, Ceratopogonidae)
}

\author{
Carla G. Cazorla ${ }^{1}$, Maria M. Ronderos ${ }^{1,2}$, Gustavo R. Spinelli ${ }^{1}$, S.R.S. Torreias ${ }^{3}$ \& Ruth L. Ferreira Keppler ${ }^{3}$
}

'División Entomología, Museo de La Plata, Paseo del Bosque s/n, 1900 La Plata, Argentina. carlacazorla@fcnym.unlp.edu.ar

1-2 División Entomología, Museo de La Plata, CCT-CEPAVE, Paseo del Bosque s/n, 1900 La Plata, Argentina. ronderos@fcnym.unlp.edu.ar ${ }^{3}$ INPA, Instituto Nacional de Pesquisas da Amazônia, André Araújo, 2.936, Petrópolis Manaus, Brasil.

\begin{abstract}
A new species of Stilobezzia Kieffer from the Neotropical Region (Diptera, Ceratopogonidae). A new species from the Neotropical Region, Stilobezzia (Stilobezzia) pseudopunctulata Cazorla \& Ronderos, is described and illustrated based on male and female adults and pupal exuviae. Adults were collected in the Argentinian provinces of Chaco, Formosa, Corrientes and Buenos Aires, and in Santa Cruz, Bolivia. The pupa was collected from mats of floating aquatic macrophytes in a lagoon in Ilha da Marchantería, in the vicinities of Manaus, Brazil. This new species is compared with its similar congener Stilobezzia punctulata Lane, from which it can be mainly distinguished by the wing with only two dark spots, the parameres longer and hook-shaped, the pupal respiratory organ with 11-12 pores and the very short apicolateral processes of the anal segment.
\end{abstract}

KEYWORDS. Argentina; Brazil; pupa; Stilobezzia pseudopunctulata sp. nov., taxonomy.

RESUMO. Uma espécie nova de Stilobezzia Kieffer da Região neotropical (Diptera, Ceratopogonidae). Uma espécie nova da Região Neotropical, Stilobezzia (Stilobezzia) pseudopunctulata Cazorla \& Ronderos, é descrita e ilustrada a partir de adultos macho e fêmea e exúvia pupal. Os adultos foram coletados nas províncias argentinas de Chaco, Formosa, Corrientes e Buenos Aires e em Santa Cruz, Bolívia. A pupa foi coletada em tapetes de macrófitas aquáticas flutuantes em um lago na Ilha de Marchantaria, nas proximidades de Manaus, Brasil. Esta espécie nova é comparada com a sua congênere semelhante Stilobezzia punctulata Lane, a partir da qual pode ser distinguida principalmente pela asa com apenas duas manchas escuras, parâmeros mais longos e em forma de gancho, órgão respiratório da pupa com 11-12 poros e processo apicolateral do segmento anal muito curto.

PALAVRAS-CHAVE. Argentina; Brasil; pupa; Stilobezzia pseudopunctulata sp. nov.; taxonomia.

Stilobezzia Kieffer is a large and diverse genus of Ceratopogonidae, worldwide in distribution. The adult females are important predators on other small insects, and the immatures stages are found in a wide variety of aquatic and semiaquatic habitats, including streams, lakes and ponds margins, puddles, swamps, rice fields, rock pools, and tree holes (de Meillon \& Wirth 1991; Cazorla et al. 2006).

Despite the great importance of knowing the ontogeny, immatures of Stilobezzia have been poorly studied. Of the 69 species of the genus recorded from the Neotropical region by Borkent (2011), the larvae of only 3 species and the pupae of 13 species have been described (Borkent \& Spinelli 2007; Ronderos et al. 2008; Ronderos et al. 2012).

During the last 6 years, several collecting trips were performed to different provinces of Argentina that have yielded specimens of Stilobezzia deposited in the Museo the La Plata, Argentina (MLP). The study of this material, as well as of other from the collection of the U.S. Museum of Natural History (USNM) revealed the presence of one unknown species of Stilobezzia. Besides, during a recent entomological survey carried out in the vicinities of Manaus, Brazil, a single pupa of Stilobezzia was collected and posteriorly identified as belonging to the same species from the emerging adult. The purpose of this paper is to describe and illustrate this new species of Stilobezzia (Stilobezzia) through the adult and pupal stages.

\section{MATERIAL AND METHODS}

Adult specimens were collected with Malaise and light traps and with sweep nets, preserved in $70^{\circ}$ ethanol and subsequently slide mounted. They were examined, measured and drawn with a binocular compound microscope with an attached camera lucida.

The pupa was collected from mats of floating aquatic macrophytes: Eichhornia crassipes (Mart.) Solms; Pistia stratiotes L. and Salvinia auriculata Aubl., in a lagoon in Ilha da Marchantería, Manaus, Brazil, with average of water temperature of $27-28^{\circ} \mathrm{C}$ and $\mathrm{PH}$ of 6-8. It was carried back to the laboratory with a drop of water and observations were done daily, until adult emergence. Adult was allowed to harden for 24 hours before being preserved to ensure its pigmentation was complete.

Pupal exuviae and adults were slide-mounted in Canada balsam following the technique described by Borkent and Spinelli (2007). Ink illustrations were made with a camera lucida. Photomicrographs were taken with a digital camera Micrometrics SE Premiun, through a Nikon Eclipse E200 microscope. The map was traced from Google Earth and the track was kept in klm format. Afterwards, the format was turned into. plt through GPS Visualizer site http:// www.gpsvisualizer.com/gpsbabel/gpsbabel_convert and also drawn on OziExplorer 3.95.4 version. 
For pupal terminology see Ronderos et al. (2012) and the Manual of Central America Diptera (Brown et al. 2009) for adults. Type material is deposited in the collection of the Museo de La Plata, Argentina (MLP).

The examined slide mounted specimens of Stilobezzia (S.) punctulata Lane are deposited in the collection of the Museo de La Plata, Argentina, and were collected in the argentinian provinces of Buenos Aires, Corrientes and Formosa, in Tabasco, Mexico and in Magdalena, Colombia.

\section{RESULTS}

\section{Stilobezzia (Stilobezzia) pseudopunctulata Cazorla \& Ronderos sp. nov.}

(Figs. 1-25)

Stilobezzia punctulata Lane: Cazorla \& Marino, 2004: 77 (misident., in part, specimens from Bolivia).

Diagnosis. The only species of Stilobezzia (Stilobezzia) with the following combination of characters: femora and tibiae peppered with dark spots; thorax dark brown except scutellum slightly paler, with 4 strong and 2 thiner setae. Males with flagellomeres 11-9 pale brown, apex of 10, base of 11 pale, and 12-13 entirely dark brown; parameres stout, its distal portion hook-shaped. Females with distal margin of sternite 8 rounded, deeply notched mesally. Pupa with respiratory organ with 11-12 pores opening on apical margin and apicolateral processes very short.

Male. Head (Fig. 1). Brown. Antenna with flagellomeres 1-9 pale brown, apex of 10, base of 11 pale, 12-13 dark brown; plume dark brown, well developed; antennal ratio 0.84-0.86 $(0.85, \mathrm{n}=2)$. Palpus dark brown; third segment stout with subapical sensory pit, fifth segment as long as third; palpal ratio 3.50-3.67 $(3.60, \mathrm{n}=4)$.

Thorax. Scutum dark brown; scutellum slightly paler with 4 strong, 2 thinner setae; postscutellum dark brown. Legs pale brown; femora, tibiae peppered with dark spots; distal apex of tibiae dark brown; tarsomeres pale; coxae dark brown; tarsomeres 1 of foreleg, midleg with row of 4-5 thin spines; tarsomere 1 of hindleg with stout basal spine, distal spine thiner; prothoracic TR 2.00-2.27 (2.18, $\mathrm{n}=4)$; mesothoracic TR 2.21-2.51 (2.42, $\mathrm{n}=4)$; metathoracic TR 1. 78-1.86 (1.84, $\mathrm{n}=4$ ). Wing (Fig. 2) length 1.47-1.67 (1.55, $\mathrm{n}=4) \mathrm{mm}$; width $0.49-0.57(0.52, \mathrm{n}=4) \mathrm{mm}$; membrane slightly infuscated with two dark spots, one on r-m crossvein, smaller one at apex of second radial cell; second radial cell 3.12$4.25(3.60, \mathrm{n}=3)$ times longer than first; cubital fork at level of beginning of r-m crossvein. Halter brown.

Abdomen. Pale brown with lateral brown spots. Genitalia (Fig. 3): tergite 9 not produced beyond apex of gonocoxites, posterior margin rounded; sternite 98.5 times broader than long, with shallow posteromedian excavation; sternite 10 rounded, slightly produced beyond base of cerci; cerci short, subparallel, spiculated. Gonocoxite stout, 2.04 times longer than greatest breadth; gonostylus slightly shorter than gonocoxite, curved, basal half stout, narrowing to tip. Parameres stout, separate; basal apodeme strong; proximal portion curved, slender, sclerotized; mid portion greatly expanded; distal portion narrowed, elongated, hook-shaped. Aedeagus represented by two strong, sinuous sclerites, convergent at apex.

Female. Similar to male, except for the following differences:

Head (Fig. 4). Antenna with flagellomeres dark brown, except basal $1 / 3$ of 1-8 pale, short base of $10-13$ pale; antennal ratio 1.31-1.59 (1.46, $\mathrm{n}=9)$. Palpus dark brown; palpal ratio 2.75-3.57 (3.11, $\mathrm{n}=14)$. Mandible with 6-7 teeth.

Thorax. Scutellum with 4 strong setae. Legs (Figs. 6-8): hind tibial comb with 7 spines; prothoracic TR 2.00-2.27 (2.17, $\mathrm{n}=14)$; mesothoracic TR 2.00- $2.73(2.44 \mathrm{n}=14)$; metathoracic TR $1.92-2.50(1.93, \mathrm{n}=14)$; claw slightly shorter than tarsomere 5 in all legs, with basal tooth. Wing (Fig. 5) length $1.51-2.18(1.79, \mathrm{n}=14) \mathrm{mm}$; width $0.61-0.79(0.62, \mathrm{n}=12)$ $\mathrm{mm}$; second radial cell 3.00-4.50 (3.60, $\mathrm{n}=13)$ times longer than first; cubital fork at level of base of r-m crossvein.

Abdomen (Fig. 9). Pale brown with brown spots. Genitalia: anterior margin of sternite 8 nearly straight, posterior margin rounded distally, deeply notched mesally; sternite 10 short, with 4-5 pairs of setae; cercus rounded. Two ovoid spermathecae (Fig. 9), measuring 8.8 by $6.8 \mu, 7.8$ by $5.9 \mu$ respectively; necks short, not sclerotized.

Female pupal exuviae (Figs. 10, 12-24). Length 4.20 (n $=1) \mathrm{mm}$. Cephalothorax length $1.72(\mathrm{n}=1) \mathrm{mm}$; width 1.03 $(\mathrm{n}=1) \mathrm{mm}$. General coloration uniformly brown, body surface smooth. Operculum (Figs. 10, 12) disc wider than long, smooth, rounded dorsally; small anteromarginal seta (am) (Fig. 12) located on very small tubercle, with pore at tubercle base; posterior margin almost straight (broken in the available exuviae), each side of mesal portion with wrinkled raised areas; OL $0.28 \mathrm{~mm}$; OW $0.18 \mathrm{~mm}$; OW/OL 0.64. Thorax surface smooth, with medial crest gently crenulated. One short, thin anterodorsal sensilla (ad) with associated pore (Fig. 21); two dorsomedial sensillae ( $\mathrm{dm})$, one minute seta, other long, thin seta, with associate pore (Fig. 20); three dorsolateral sensillae (dl), one short seta, other long, thin, seta, other short, stout setae (Fig. 20); 4 dorsal sensillae (d) clearly distinguished (Fig. 19): two elongate, thin setae, other peg, other pore. Respiratory organ (Figs. 10, 13) dark brown, with 1112 pores opening on apical margin; length $0.20 \mathrm{~mm}$; pedicel (Fig. 14) slightly darker, short; length $0.013 \mathrm{~mm}$; P/RO 0.065. Two ventromedian campaniform sensillae (vm); two thin ventrolateral sensillae (vl), one short, other elongate with associated pore (Fig. 23). Abdominal tubercles short, with single, pointed apex or, if very small, some rounded. First abdominal segment (Figs. 10, 22) with sensillae as follows: 2 anterior setae, one long, thin, other minute seta; 3 lateral setae on very small tubercle, two short, one minute; 2 posterior setae, one medium-sized, thin seta, other minute seta with posterior associated pore; one posterior pore medial to posterior setae. Fourth abdominal sensillar pattern (Figs. 10, 15-17, 24) as follows: two dorsal anterosubmarginal (d.a.s.m.), i 


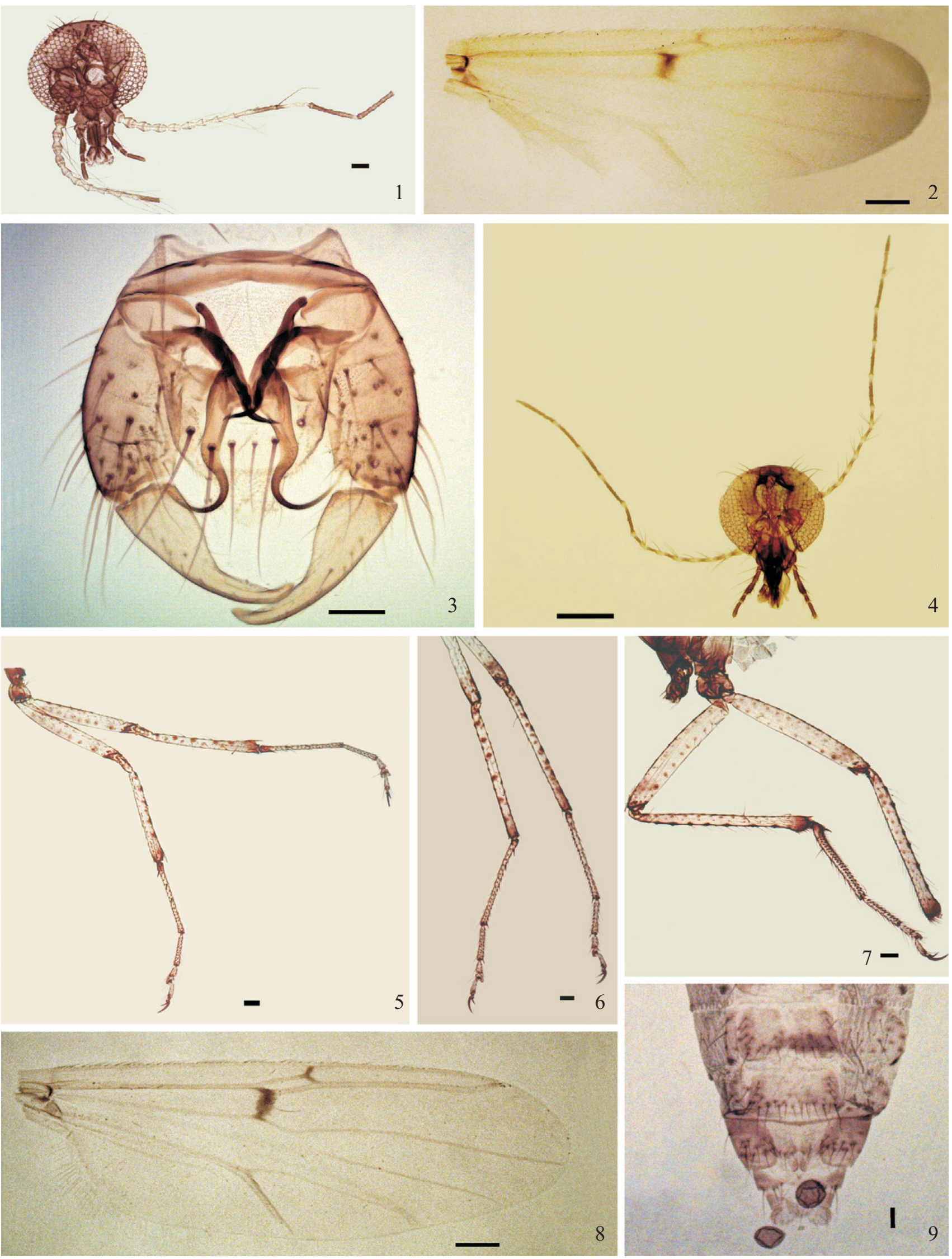

Figs. 1-9. Stilobezzia pseudopunctulata Cazorla \& Ronderos, adult - Figs. 1-3: male. Figs. 4-9: female: 1, 4, head; 2, 8; wing; 3, genitalia; 5-7, legs; 9 , tip of abdomen. Scale bars $0.05 \mathrm{~mm}$. 

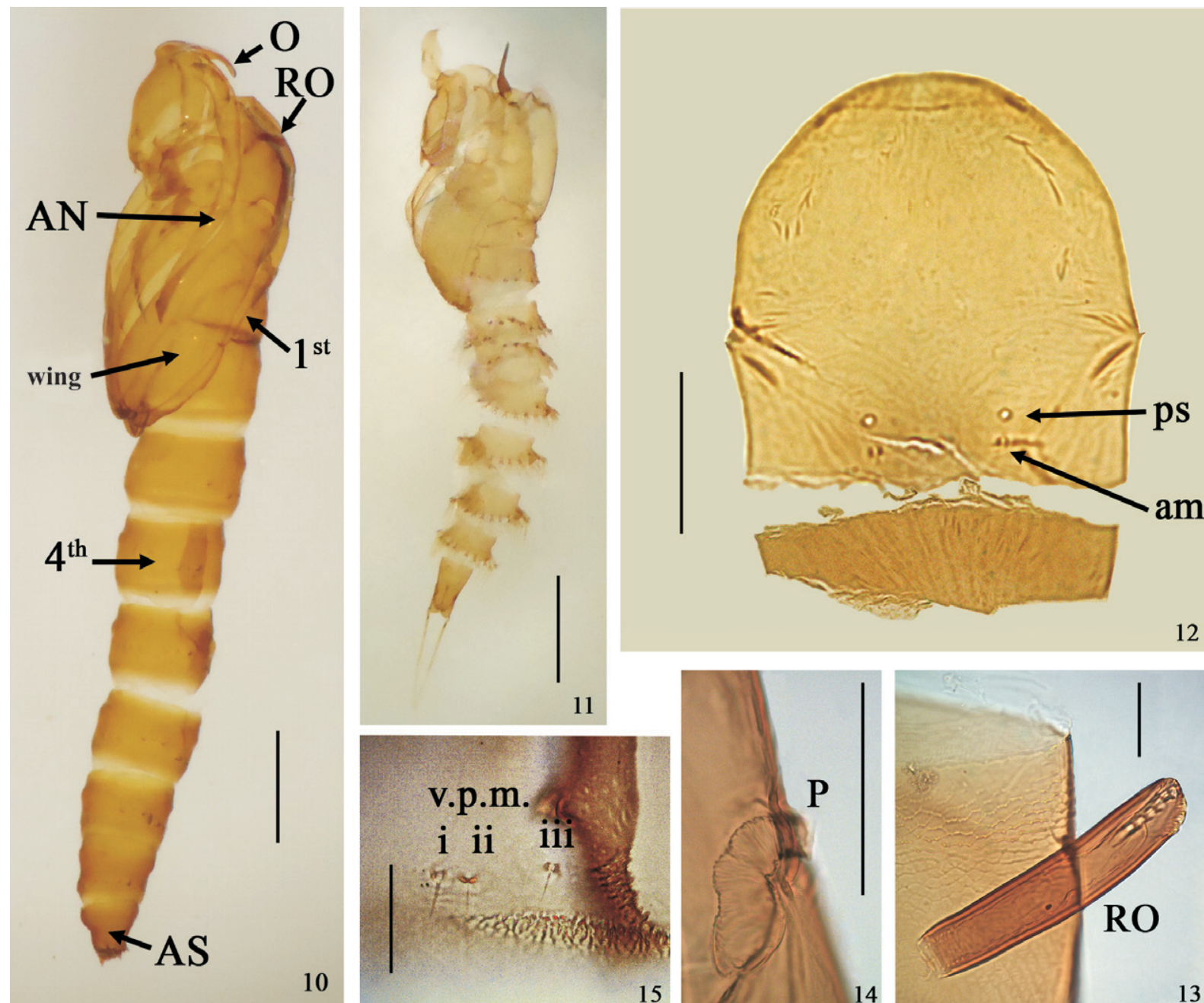

12
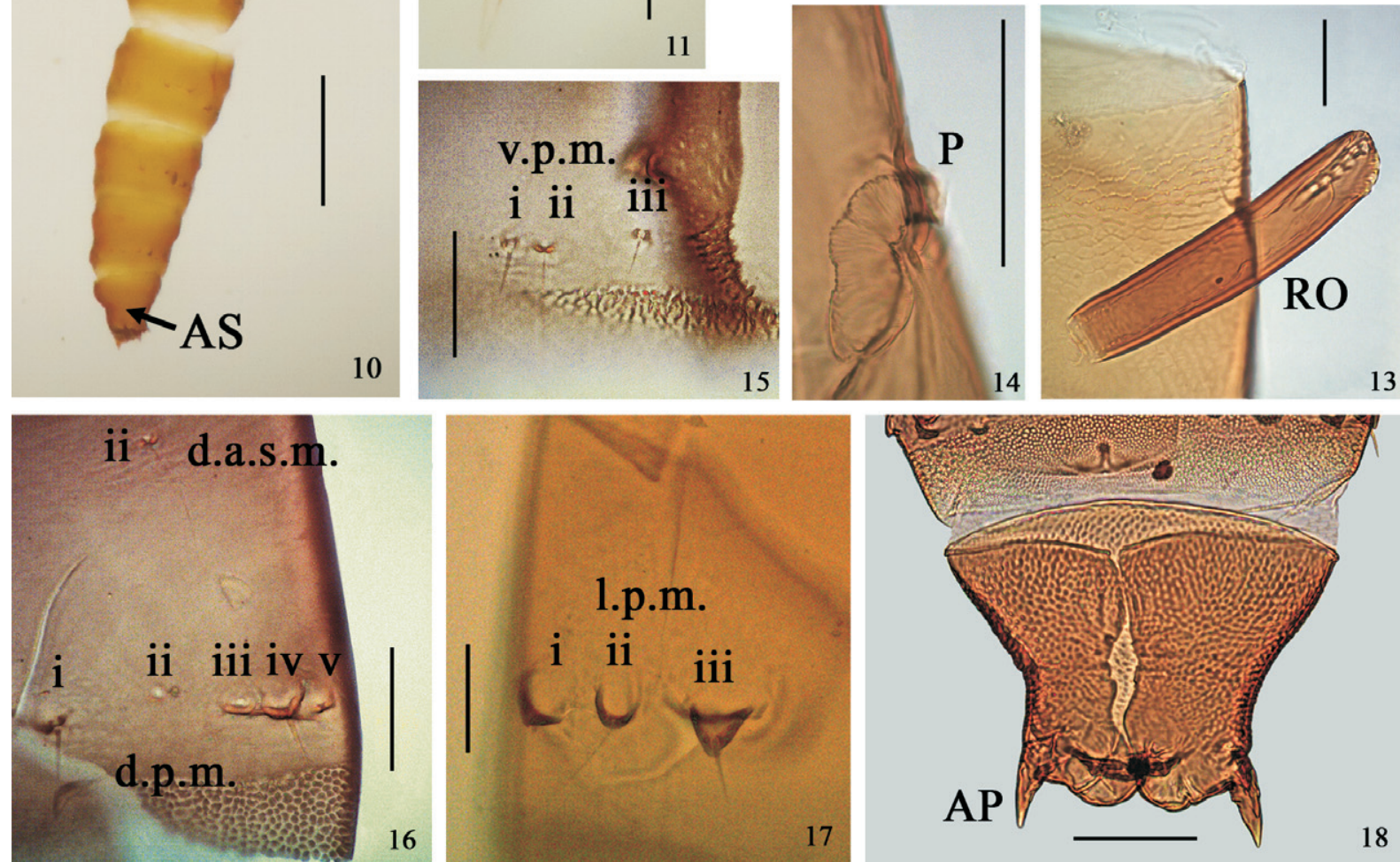

13

Figs. 10-18. Stilobezzia pseudopunctulata Cazorla \& Ronderos, female pupa -Figs. 10, 12-18; Fig. 11: Stilobezzia punctulata, entire pupa (lateral view). 10 , entire pupa (lateral view); 12, operculum; 13, respiratory organ; 14, pedicel; 15-17, $4^{\text {th }}$ abdominal segment (ventral, dorsal and lateral view); 18, anal segment (ventral view). Scale bars $0.05 \mathrm{~mm}$. Anteromarginal setae (am); antenna (AN); apicolateral processes (AP); anal segment (AS); operculum (O); pedicel (P); pore at tubercle base (ps); respiratory organ (RO); Fourth abdominal segment setae: dorsal anterosubmarginal setae (d.a.s.m.); dorsal posteromarginal setae (d.p.m.); lateral posteromarginal setae (l.p.m); ventral posteromarginal setae (v.p.m.).

pore, ii long, thin seta on rounded, small base; 5 dorsal posteromarginal (d.p.m.), i, medium-sized, thin seta, ii-iii pore, iv-v longer setae, thinner than i; two ventro anterosubmarginal (v.a.s.m.), minute pores; one latero anterosubmarginal (1.a.s.m); 3 latero posteromarginal (1.p.m.), long, thin setae on small bases, i stouter, shorter than ii-iii; 3 ventral posteromarginal (v.p.m.), medium-sized, thin setae each on very small tubercle, ii longer, thinner than i, iii. Anal segment (Fig.18) surface covered with small spicules; apicolateral processes triangular, very short, strong, base 


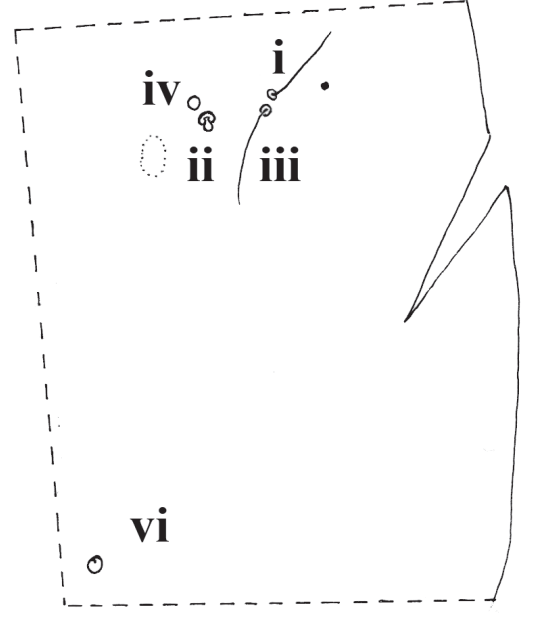

19
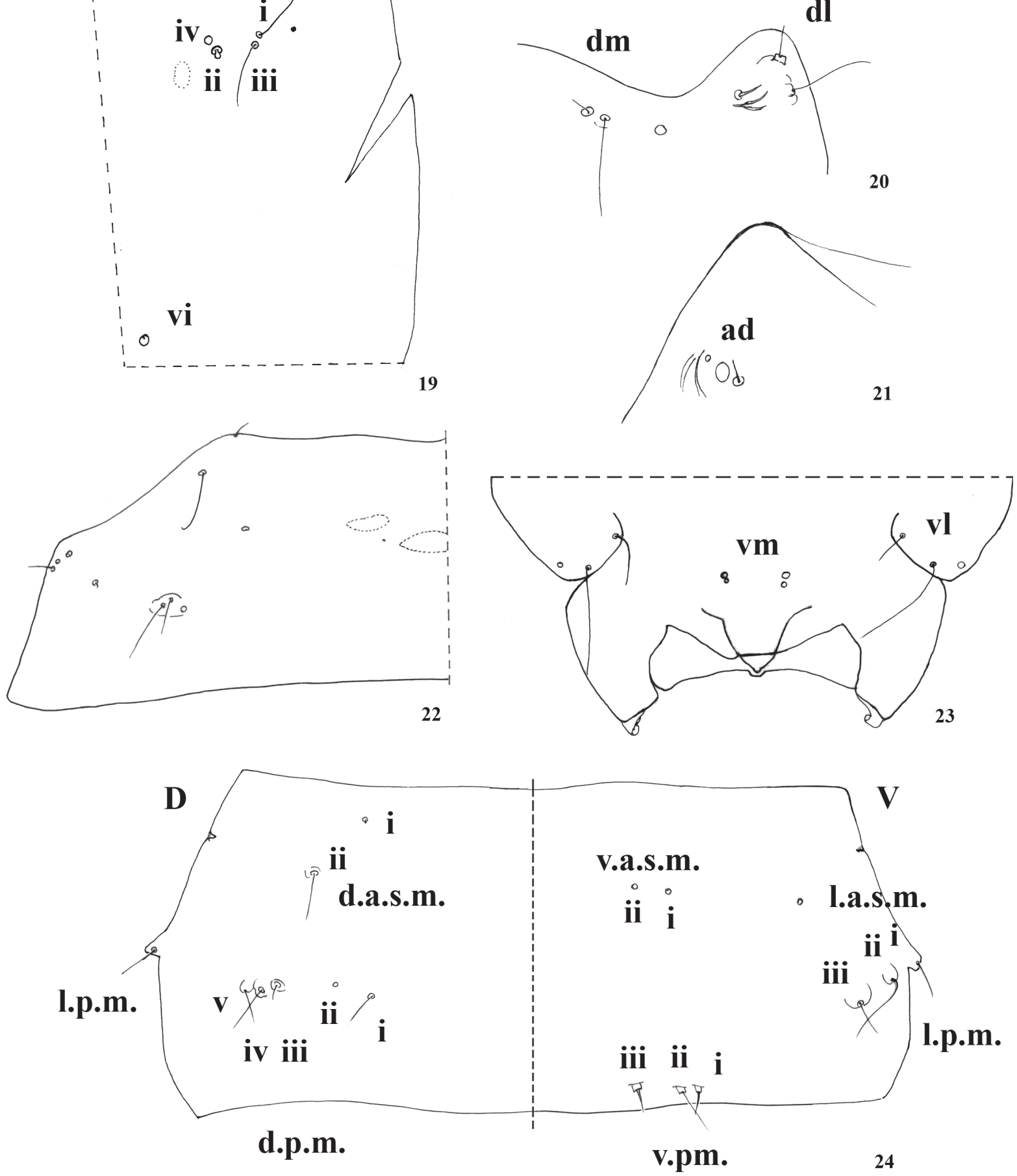

Figs. 19-24. Stilobezzia pseudopunctulata Cazorla \& Ronderos-19, dorsal setae; 20, dorsolateral seta and dorsomedial setae; 21 , anterodorsal setae; 22, detail $1^{\text {st }}$ abdominal segment (dorsal view); 23, ventromedian and ventrolateral setae; 24 , detail $4^{\text {th }}$ abdominal segment (dorsal and ventral view). Scale bars $0.05 \mathrm{~mm}$. Anterodorsal setae (ad); dorsolateral seta (d); dorsomedial setae (dm); ventrolateral setae (vl); ventromedian setae (vm). Fourth abdominal segment setae: dorsal anterosubmarginal setae (d.a.s.m.); dorsal posteromarginal setae (d.p.m.); lateral anterosubmarginal seta (1.a.s.m.); lateral posteromarginal setae (1.p.m); ventro anterosubmarginal (v.a.s.m); ventral posteromarginal setae (v.p.m.).

wide, gently curved, length $0.28 \mathrm{~mm}$, width $0.32 \mathrm{~mm}$, apicolateral process length $0.065 \mathrm{~mm}, 0.025 \mathrm{~mm}$.

Male pupa. Unknown.

Distribution. Brazil (Amazonas), Bolivia (Santa Cruz), Argentina (Formosa, Chaco, Corrientes and Buenos Aires provinces).
Type material. Holotype male, Argentina, Chaco, $35 \mathrm{~km}$ Tres Estacas, 278'14,5" S- 613'ㄹ' W, 27-XI-2007, Marti \& Pelliza, at light; allotype female, Argentina, Chaco, Chaco National Park, $26^{\circ} 48^{\prime} 25^{\prime \prime} \mathrm{S}, 56^{\circ} 26^{\prime}$ 36.5" W, 17/28-X/2009, R. Pfoh, at light (MLP). Other paratypes: 17 females, 2 males, as follows: same data as holotype, 1 female (MLP); same data as allotype, 1 female, 1 male (INPA); same data except $26^{\circ} 48^{\prime} 25^{\prime \prime} \mathrm{S}$, 


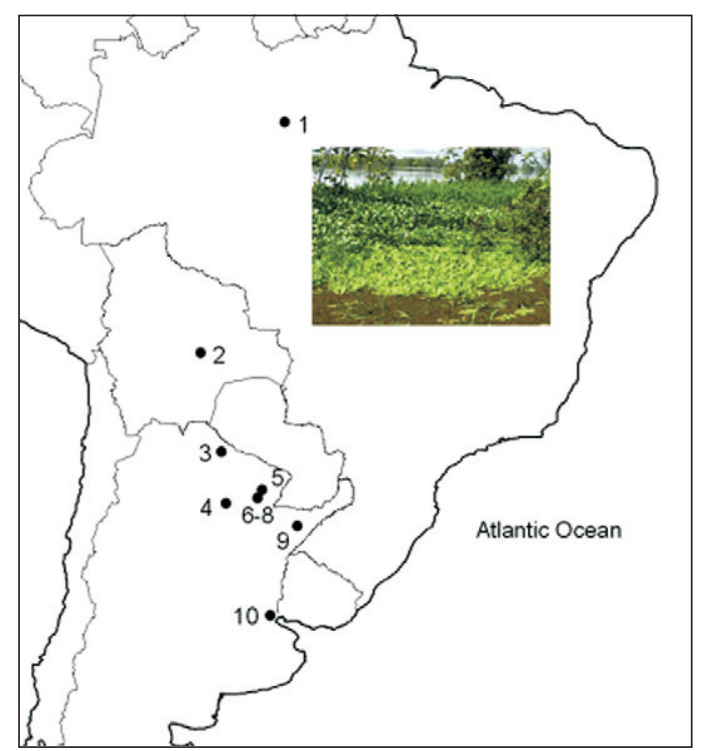

Fig. 25. Map of species distribution and collecting site. 1. Brazil, Amazonas, Iranduba, Ilha da Marchantaria; 2, Bolivia, Santa Cruz; 3-10, Argentina: 3, Formosa; 4-8, Chaco; 9, Corrientes; 10, Buenos Aires.

$59^{\circ} 36^{\prime}$ 26.5' 'W, 76 m, 24/27-IX-2009, C. Cazorla, 1 female, 1 male (MLP); same data except $26^{\circ} 48^{\prime} 20.1$ 'S, $59^{\circ} 36^{\prime} 32^{\prime \prime} \mathrm{W}, 24 / 27-I X-2009$, C. Cazorla - C. Melo, 2 females, Malaise trap (MLP); Argentina, Buenos Aires, Campana, Isla Talavera, 18-XI-2004, G. Spinelli, 2 females, at light (MLP); Argentina, Corrientes, Colonia Pellegrini, 1/7-XII-2001, M. C. Coscarón, 2 females, Malaise trap (MLP); Argentina, Formosa, Ing. Juarez V-2005, H. Calandra, 1 female, at light (MLP); Argentina, Formosa, Estancia La Marcela, $35 \mathrm{Km}$ E El Colorado, V-2005, J. Williams, 2 females, at light (MLP); Bolivia, 60 mi N Santa Cruz, 2-I-1960, R. B. Cumming, 2 females (USNM). Brazil, Amazonas, Iranduba, Ilha da Marchantaria, Lago Grande, 28-XII-2010, F. Díaz-P. Marino, 1 female with pupal exuviae (MLP).

Taxonomic Discussion. This new species is very similar to Stilobezzia (S.) punctulata Lane. Adults of the latter species can be distinguished from $S$. (S.) pseudopunctulata sp. nov. by the presence of three dark spots on the wing membrane, by the paler thorax with dark spots, and by the shorter and slightly curved parameres.

The pupa of $S$. (S.) punctulata (Fig. 11) differs from $S$. (S.) pseudopunctulata sp. nov. by the respiratory organ with a basal row of five dorsal pores and an apical row of 18 pores, the very long and slender apicolateral processes of the anal segment, and by the abdominal segments with conspicuous tubercles with elongate and bifurcated setae.

The sharply pointed and anteriorly directed respiratory organ of the pupa of $S$. (S.) punctulata appears to be related to its capacity to obtain air from hydrophites (Cazorla \& Marino 2004). On the other hand, some features of the pupa of $S$. (S.) pseudopunctulata sp. nov., such as the mediumsized respiratory organ and short apicolateral processes of the anal segment, are typical of ceratopogonids that live in shallow and clean waters.

\section{ACKNOWLEDGMENTS}

We are grateful to PIP 1724 and PIP 0381- CONICET for the financial support during this investigation. Our gratitude to Nélida Caligaris and Luis Giambelluca for technical assistance.

\section{REFERENCES}

Borkent, A. 2011. World species of biting midges (Diptera: Ceratopogonidae). Available from http://www.inhs.uiuc.edu/research/FLYTREE/ CeratopogonidaeCatalog.pdf (accessed at 10/02/2012).

Borkent, A. \& G. R. Spinelli. 2007. Neotropical Ceratopogonidae (Diptera: Insecta). In: J. Adis; J. R. Arias; G. Rueda-Delgado \& K. M. Wnatzen (eds.). Aquatic Biodiversity in Latin America (ABLA). Vol. 4, Sofia-Moscow, Pensoft, 198 p.

Brown, B. V.; A. Borkent; J. M Cumming; D. M. Wood; N. E. Woodley \& M. A. Zumbado. 2009. Manual of Central American Diptera. Vol. 1, Ottawa, NRC Research Press, 714 p.

Cazorla, C. G.; F. Diaz \& M. M. Ronderos. 2006. Redescription of pupa and adult of Stilobezzia fiebrigi Kieffer 1917 (Diptera: Ceratopogonidae). Transactions of the American Entomological Society 132: 111-119.

Cazorla, C. G. \& P. I. Marino. 2004. The pupa of Stilobezzia punctulata Lane from Peruvian Amazonia. (Diptera: Ceratopogonidae). Amazoniana 18: 75-80.

de Meillon, B.\& W. W. Wirth. 1991. The genera and subgenera (excluding Culicoides) of the Afrotropical Biting Midges (Diptera: Cerratopogonidae). Annals of the Natal Museum 32: 27-147.

Ronderos, M. M.; C. G. Cazorla; G. R. Spinelli \& D. S. Carrasco. 2008. Description of immature stages and adult diagnosis of Stilobezzia coquilletti Kieffer 1917 (Diptera : Ceratopogonidae). Zootaxa 1958: $31-40$.

Ronderos, M. M.; G. R. Spinelli \& A. Borkent. 2012. A peculiar new species of Stilobezzia Kieffer breeding in bamboo internodes in northeastern Argentina (Diptera: Ceratopogonidae). Aquatic Insects 34: 1-17. 